\author{
TREATMENT OF RECURRENT MAXILIARY TUMORS \\ KEIKO KIKAWADA, M. D. \\ Department of Otorhinolaryngology, Faculty of Medicine \\ University of Tokyo, Tokyo \\ (Director: I. Sato, M. D.)
}

Clinical observations were made on 93 patients with maxillary tumors who had been treated with the combined therapy without arterial infusions in recent 9 years since 1968. Thirty patients of the 93 had recurred one or more times. A discussion was made on their pathological classifications, time and regions of recurrences, range of extension, and the standard treatment.

According to clinical findings in each case, repetitive removals of tumors or necrotic tissues were performed on out-patient basis with a suction tip, a curette, or forceps after a period of regional applications of anticancerous ointment and subsequent degeneration of active tumors. In some cases resistive to the routine therapy, further irradiation under inhalation of the mixed gas $\left(5 \% \mathrm{CO}_{2}\right.$ and $95 \% \mathrm{O}_{2}$ ) and the removal of necrotic tissues were performed.

It was claimed that the use of the above strategy, taking the general condition such as the immune response or the nutritional status into account, could lead to the preservation of the structure and function of the diseased region and to successful rehabilitation of the patient.

\title{
A $82-0027-33399$ \\ 上顎癌三者併用療法とくに再発処置について
}

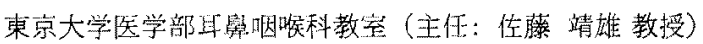

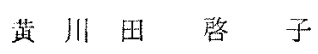

\section{I.はじめに}

頭䫋部癌治療の目的は，発病と同しく精神的にも肉体 的にも充実した生活を続けさせることである゙232．治潦 にあたっては，それぞれの時期に応じて各種治潦法をう まく組み合甘て, 再発症例でも絽の根治上同時㐳, 形態 上機能を保存して社会復慢を続けられるよう努めてい る。治療で瘦を変性除去する際に，治療配量か子多くなる と, 周四健常組織も障害を受け，汃えてて再発しやすい ほかりか，ときに修復術も必要となる。乞こで一次治療 はもちろん，再発処置でも周囲健常組織方障害をらけは いうちに治療をすませる上ろ努力している。すなわち生

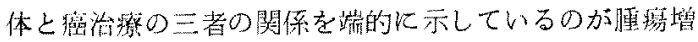

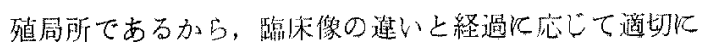

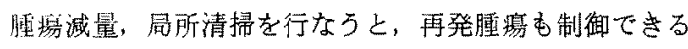
ものが多い，予後在在する毛のは一次治療上りもむし

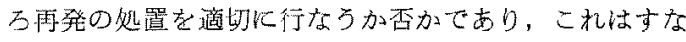
吅ち機能保存治潦七表慗一体であるといえる。をこで最 近私どもが経験した上影癌の再発例をとりあげ，日筑讋 療で行な弓具体的な治潦操作，扣上びをの意義について

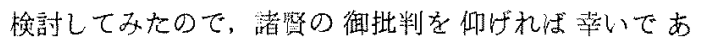
る.

\section{II. 刘象および方法}

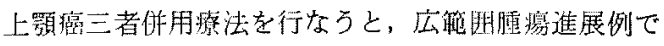
毛形態上機能况保存して社会復雨例が多く，步存率も70

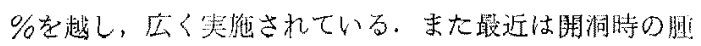



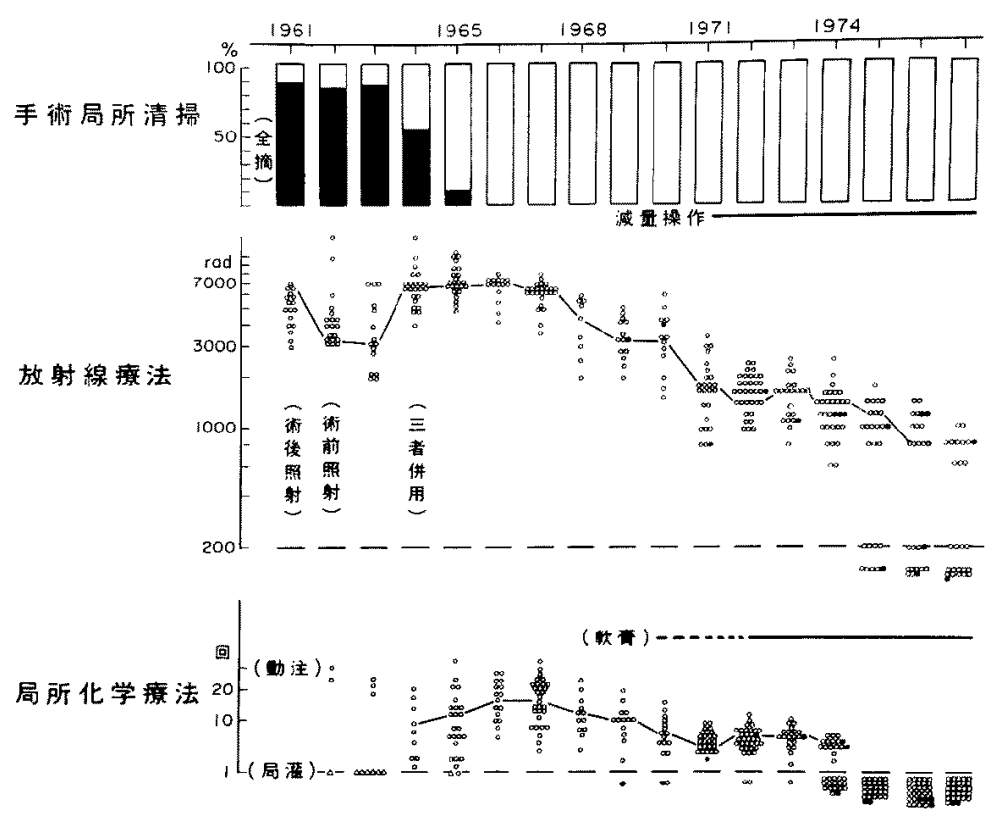

第 1 図上顎癌治療法の变遷

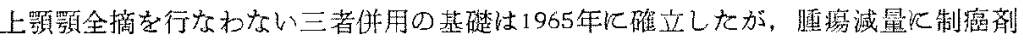

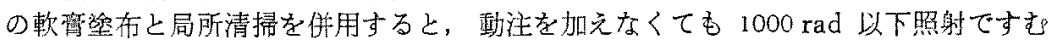
ようになった。

○印：動注委含ぬ大症例 $\triangle$ 印：局所灌流例一印：放射楾治療抵抗例

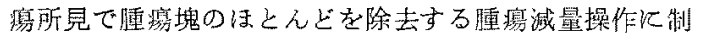

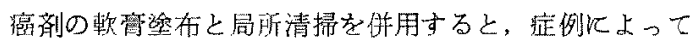
は動注を扣えなくとも $1000 \mathrm{rad}$ 以下照射ですむようれ なっだ第1図)。そこて1968年以降の最近9力年の

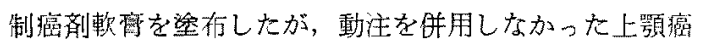
93 例を対象として，そのうち再登をみた 30 症例につい $\tau$, 病理分類, 再発時期, 部位, 再発腫痽進展度, 再発 処置の実際, 治療効果など臨床的开究を行なった。

\section{III. 成 績}

\section{1. 病理分類上再発頻度}

非動注三者併用の93例中に，腺癌と高平上皮隐の混成

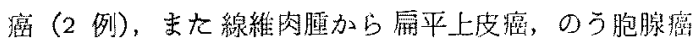

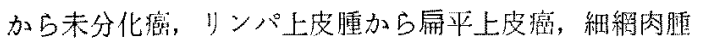
からリンパ上皮腫など組織診が再発例で変わったもの，

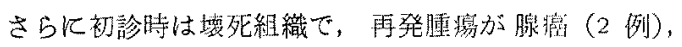

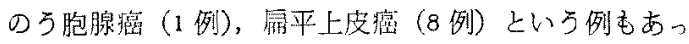

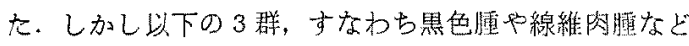

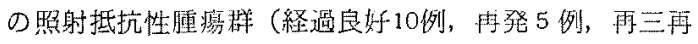

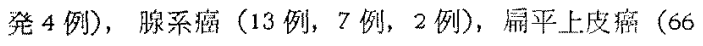

例, 35 例， 24 例) に大別して屯，三者間に 再発率に著 しい差はみられなかった。細細肉嫤（4例，1例，○例） は症例は少ないが経過良好である（第2图）。

\section{2. 再発部位亡時期}

93列中30例に再発をみたが，治䝤法扰よび猛の特殊性か らくり返し再発した症例毛あるため, 再発部位件数と再 発時期をまとめると（第1 表)，前壁軟部組織が最も多 く23件で, 中鼠甲介・箱骨, 口蓋雪肉部, 洞側・後部に つづき，反対側燃や口唇，前頭洞などもあって，再発は 各所にわたっている。再発時期は治療後 3 力月まて26件 6 力月要で 24 作上比較的早い時期が多く，2年以上経過 してから再再発頻度は少ないが 5 件あった。

\section{3. 再発腫漂の進展度}

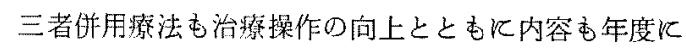

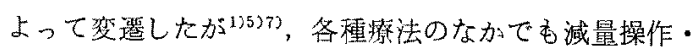
属所清掃の比重が增した最近は，照射墨も $800 \mathrm{rad}$ と照 射ゼロの二極分化の傾向を示している．そこで $400 \mathrm{rad}$ 以下照射群（23例中再発 5 例）と600 rad 1000 rad 照射群（31例中雨発12例）の計17例の再発時期之再発腄

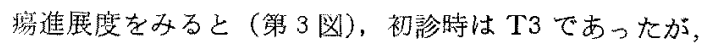




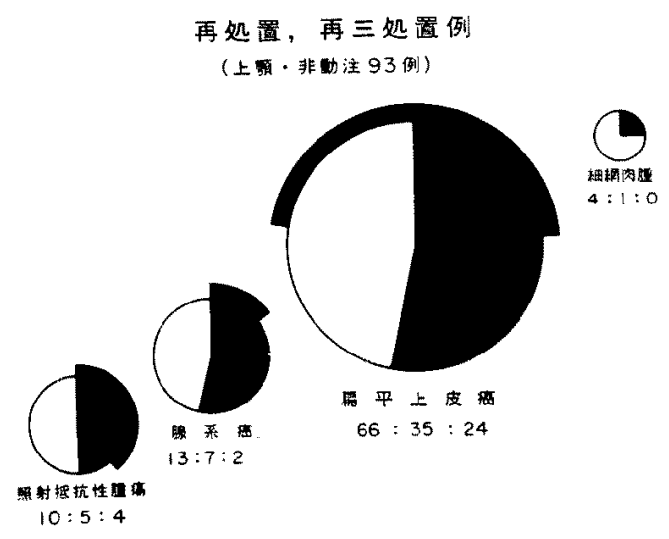

第 2 図病理分類亡再発頻度 黒色腫，線維肉腫などの照射抵抗性腫瑝群， 腺系癌，屚平上皮癌の間化再発率の著しい差は なかった、細种闪腫は症例は少ないが稀過良好 である。

\begin{tabular}{|c|c|c|}
\hline 10 & 5 & 4 \\
\hline 症例 & 再発例 & 再三再発例 \\
\hline
\end{tabular}

再発腫癔は rT126件が最委多く，rT3 7件，rT43件な

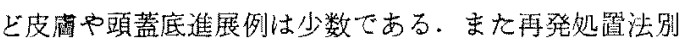
K比較してす，通院清掃ですんだものが最も多く27件
第 1 表 93 例の非動注群の阵発㭙期と部位件数

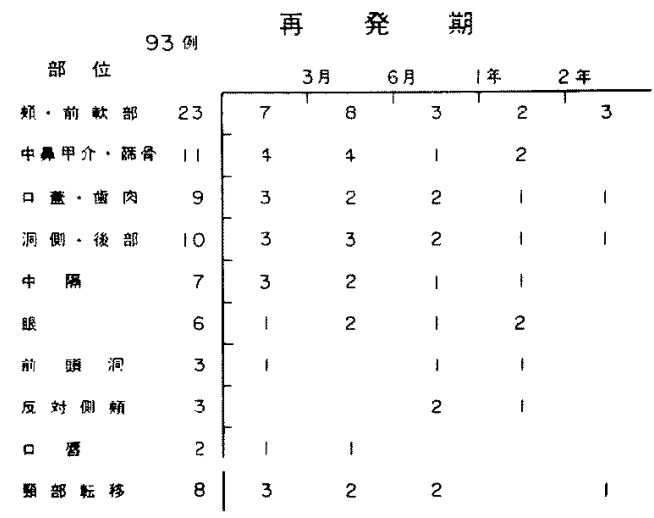

再発部位は各所にわたり，また重複してい るが，煩・前軟部は23件之最す多い。梅発時 期は治療後 3 力月から6力月までが多い。

で,ついで隀揚隇最・手術清眾15件，再照射8件であっ

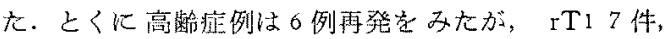
rT2 6件，rT31件の棓14件で，通院清㩑 9 件, 手赫清掃 3 件，再照射 2 件と通院清掃で粳瘳を制御しうる比率 加高い(6/14例，64\%)。

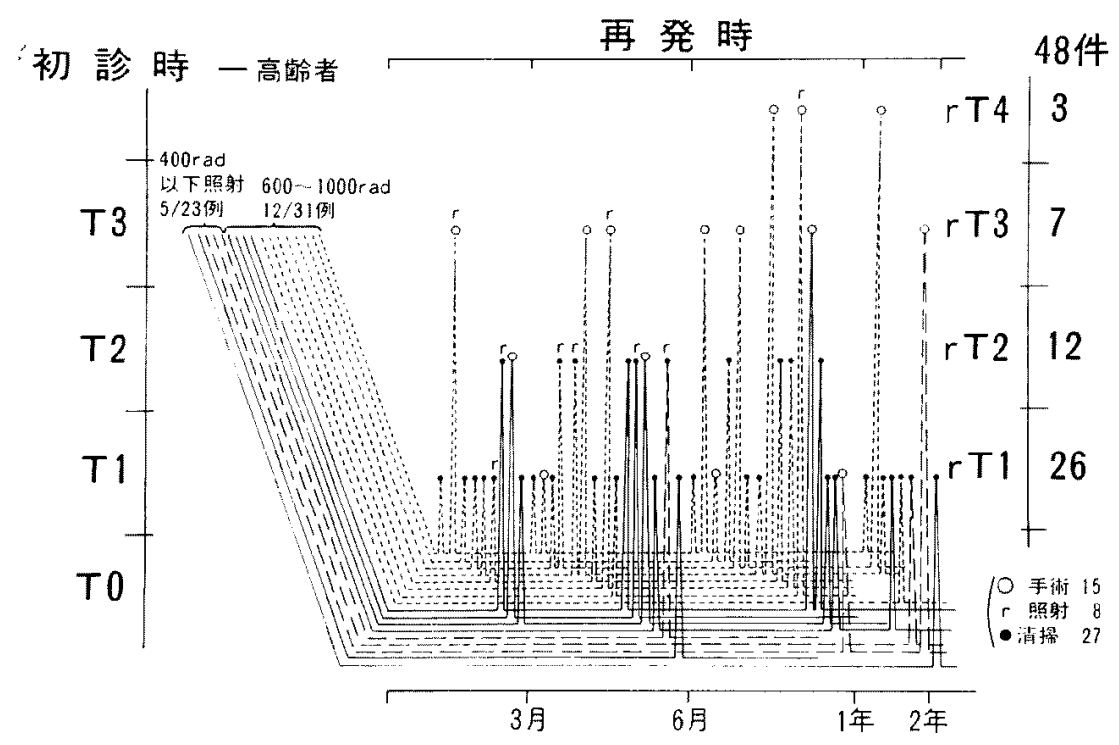

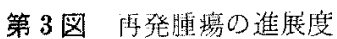

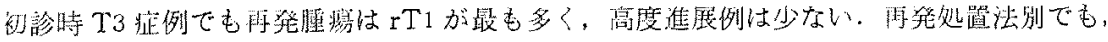

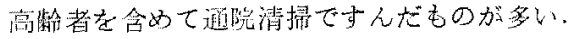




\section{4. 再発処置の実際}

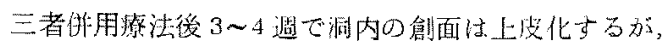

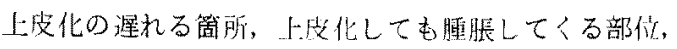
䍖他血性でフィブリンが付算した肉茅，仯粒状の硬結な

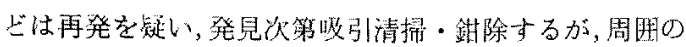
煡常組織には算用の制激を加えないようにしている，故 死や颣血はもち万え，㰞らかくブヨブヨした脱落傾间の

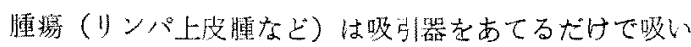

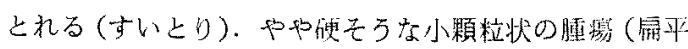
上皮癌など）は吸引器の光端でがすようにとぎとり，

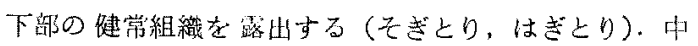

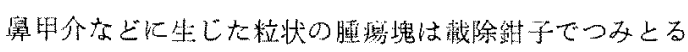
(つみとり)、その際，胿㗄はグズグズした手ごたえで切

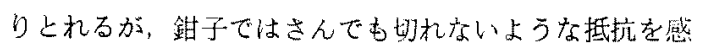
じた場合は，無理にとらない，鎚子は力をこめて切るの ではなく、盏于の重みだけでつみとる。粘膜酒に隆起は

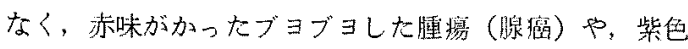

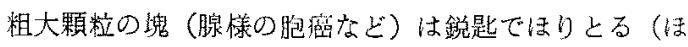
りとり).これも力索加えなくてもはとんど拊抗なくは りとれる.これらの操作はとくに林酔必要としない。

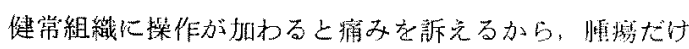
を除去するように努める。

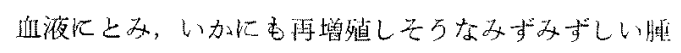

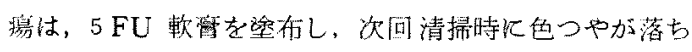
たとこるで鈿子や鋭匙てつみとり・はりとりを行なら。

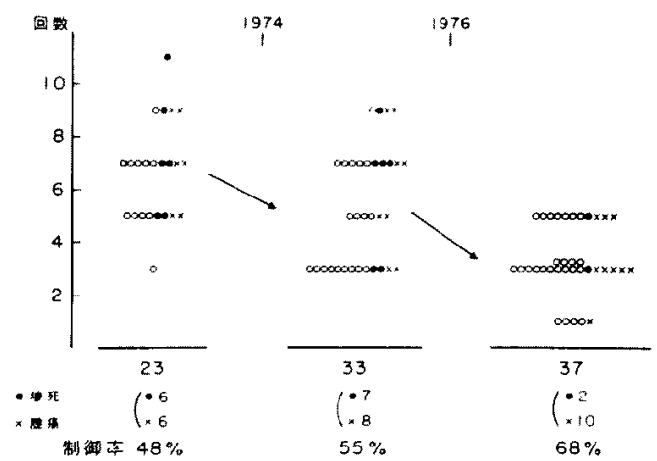

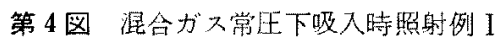

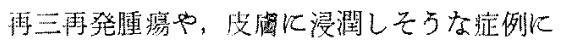
对しては，混合がス常任下吸入時照射に積極的 外来清掃を併用しているが，腄場の潞床像をみ ながら，最近性数回の照射ですんでいる，

○印: 経過良好例

$\times$ 曰1: 腫墽残存例

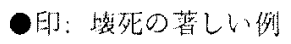

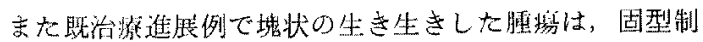
䧚用（何型，繶澘型マイトマイシンあるいはブレオマ

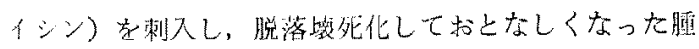

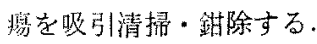

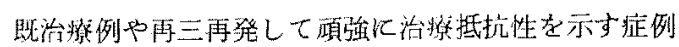

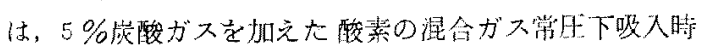

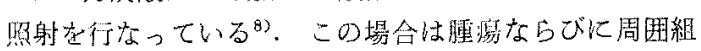

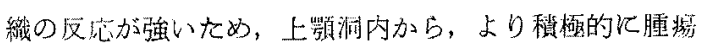

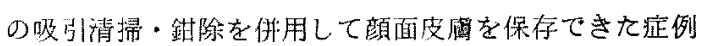

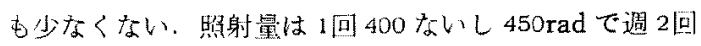
照射を行なうが，居所清揣を件用した最近は，照射回数

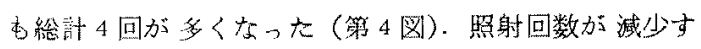

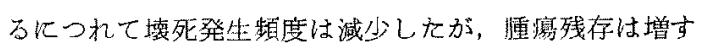

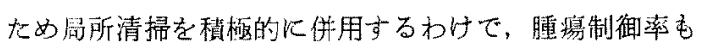
48\%か 555\%，68\%と向上してきた，また混合ガス常四

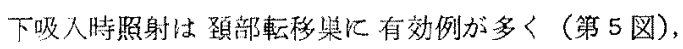

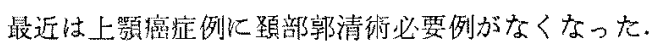

\section{5. 再処置, 再三処置効果}

治潦效果の判定は無作為抽出が必要不可从であるが， 调々の症例に最毛滴した治療を組み合わせているので, 具の学祭的対照となりえないとしても，5FU，BudR を 動注して6年以上経過した45例（生存深26\%) 老歷史的

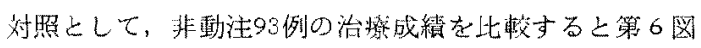
の如くてある（第6四）、外来清掃ですんだ症例の経過 はよく，照射をせさるを得なかった拉例や，再三処置が 多種炕なるにと死亡例が增加するが，治燎配星の少ない 非動注群は，再三好瞋の影響が少ない傾向がある。

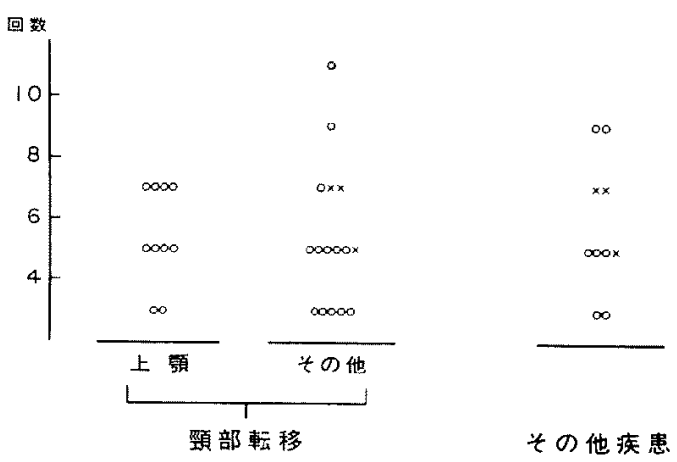

第 5 图 湜合力゙ス常生下吸入将照射例 II

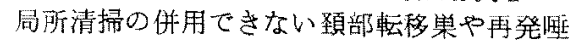
液腺堙䳨に対しては，照射量は多くなるが頚部 新清術は必要がなくなり奏施していない。

○印: 経過良好例

×印: 腄㨸残存例 


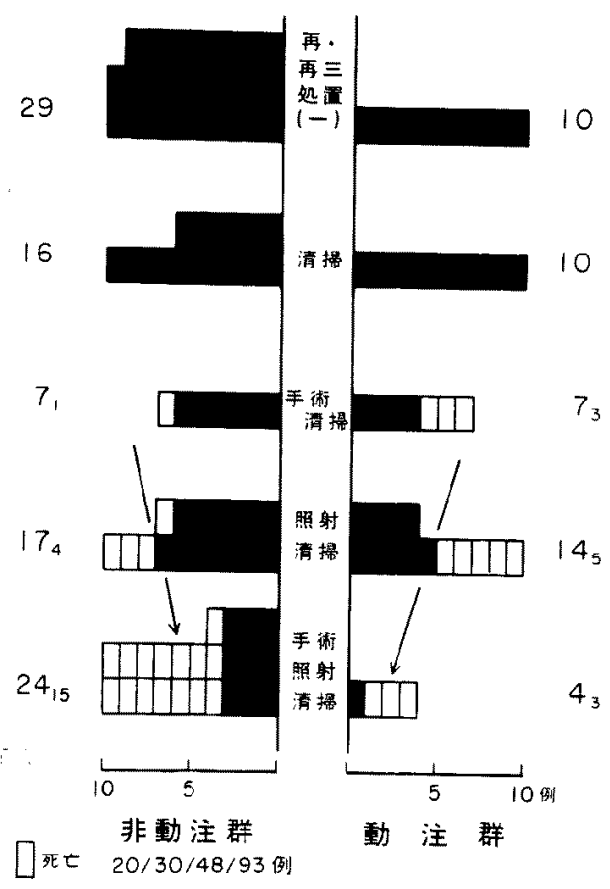

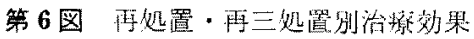

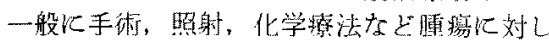
て既治療侵警の多い症例の成績は悪い傾向があ るが，非動注群は生体之睡痻之治燎の三者の関

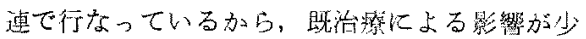
ない傾问怔ある。

\section{IV. 総括および考按}

21 世紀の頚頝部治筴の進屯力唐として注目されている

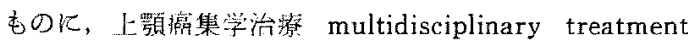
がある゙1，すなわ方科学の発達により治療法は開発され るが，高龄化社会化もすすをため，臨床像の特徽抽仙は 欠かせないと考えている、癌治療の目的を達成するため にす，広い意味での免疫的配虑下に，組織診を襄付け上 した臨床像の飓いと経過をみて，倜々の症例のそれぞれ の時期に最方適した治療を組み合わせる。生体と癌と治 燎の三者の関速を端的に示しているのが腫境增殖局所で あるから，ものさしで测れない複雑微妙な癌㭧著の治療 は，腫演活性の䛦断に徹して，哭理押ししない操作佰式

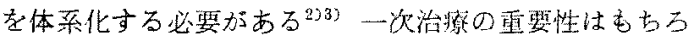

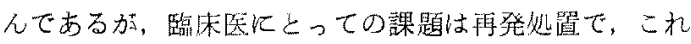
が予後を左右するといって秀過言ではない，

TNM 分類も治療前の榆查でカテゴリ一老決め, 绥ま でそのまま変画しないとされていたが，1978年の UICC

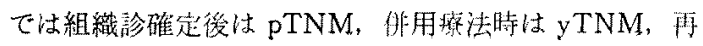

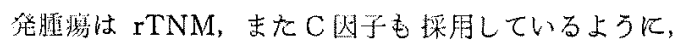
きめ細かい分類が要求され，再発起置の霍要性が㤎めb

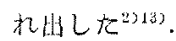

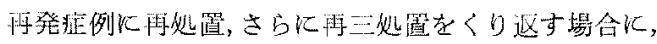
北態上機能保保は初回以上K要求される。再発したから

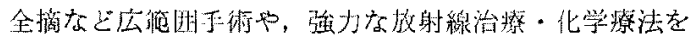

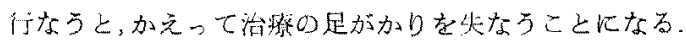

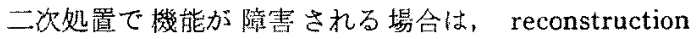
rehabilitation も考光ながら治祭をすすかるわけで，そ

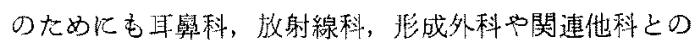
協间治漝が初回治潦以上に必要である。大の際耳覤科医 に要求されることは，彷日の臨床像の望いと経逗加見 た腫㵧活性の㟝断である

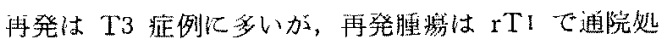
置で腫癔を制御しうるものが少なくない。また再発は屚

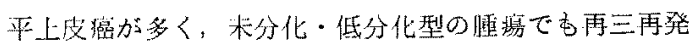
しても局在している屯のが少くない2．每回診祭の際に

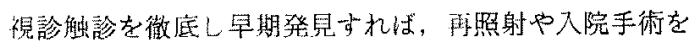
要さないものが多い324。

耶発郘位は経過観察が鈎の陸で兒落とされやすい前壁

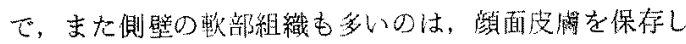
て闌洞か、デンケルに準してて趴切を行なっているためて あるう。再発は測内学蜰診すると, $1 \sim 2 \mathrm{~mm}$ 通径の硬い

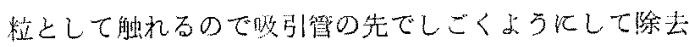

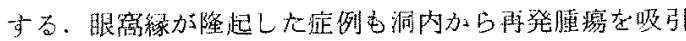
除去，あるいは鈤除で眼球を保存している。侧煩部に再

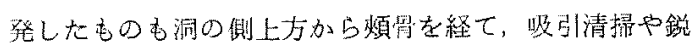

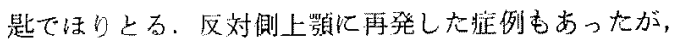
開洞清琭で制御している、視敦も重要で, 下壁，口蓋・

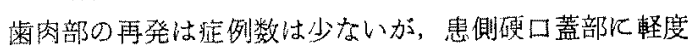
の隆起，あるいは健側比してやや発赤のある場合は注 意する。岿肉部も表面は平滑でも，球状隆起となって表 在性に小伹管の走行しているもの，発赤のあるあのは要

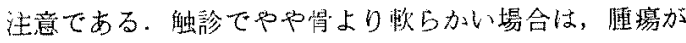

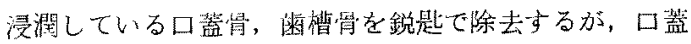

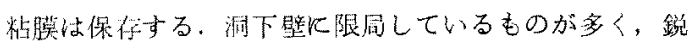

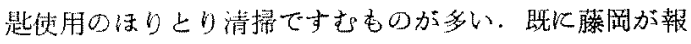

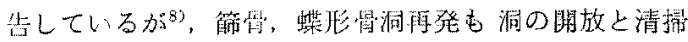
を行ない，眼窝内再発であはりとり清擂ですみ，眼球は 保存している。

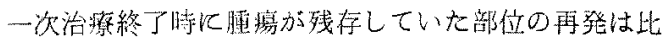

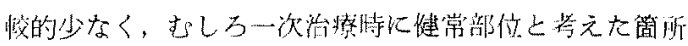

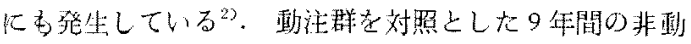


注群の治潦效果については洲崎がすでに報告しているが ら，外来清掃ですんだ应例の経過はよく，一般に再処置 再三処置が多種になるほど死亡例が增す北向がある。し

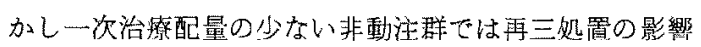
は少ない。

再発腫瑏も通院処置で制御できるものが多いため，治

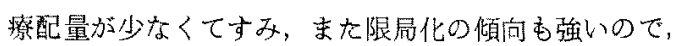
原病果進展に上る死亡例も少ないまをた組織祅も含めた 臨林像で加減した腫湯減墨，局所清掃であるから，㜞移 他因死例が增与傾向もない2333 つまり，二次・再三炕

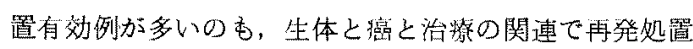
を行なったためと考えている。

高制症例では，山本が報告しているがタ，腫湯活性が 低く再発腫瘍も限局化傾向が強いが，身体機能調節が不 安定であるため，わずかの精神身体的制激化も影響安受 けて生理的平衡をくずするのや，代謝回転の低下で少な い治療配量で必要量几達し，多彩な反灾を示すなど個人 差が大きい，しかし治療原則から法出出した怔例でも， うまく治源を組み合わせ，動機づけすると潜在能力の限 界加ら回復するから，舆理押しの一律治蹽でな。しか あ高龄者であるからこそ生き伟斐を失なわ世ないために ま, 形態と機能を保存してこれまでの唇い生活歷と病態 を考え合わせ，社会復帰を続けられるように努める。呾 種悪条件の高龄者は入院加療が筑とされているが，卧床 で安静独いることは創傷治瘾の面でも社会復帰の点加 らもか党ってマイナスが多い，体重が減少してきた症例 ではサスタジェンなどの消化態栄菱剂投与で体重の回復 をはかるとともに，家族との生活几上って治潦への意欲 もわき，手術例でも10日前㣪の短期在院，長期観察上治 療操作が簡単化してきた。

兒疫学のめざましい発達とともに，腫湭治潦も新しい 角度から兒な和す必要がでてきた，免疫学的立場からは

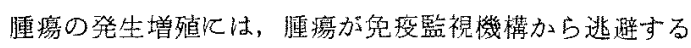

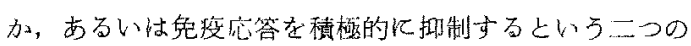
ルートが考光られる ${ }^{14}$. 治療時に抎ける癌上前所ならび

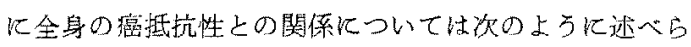
れている12713)。発癌した状態では, 癌は全身の抵杭性よ り位位の状態で增殖している，蛿の增大に伴なって全身

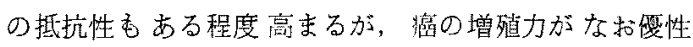
で，局所の抵抗性をむ破って增殖する。この際全身の怎 疫細胞が動異消贊されるため，宿主の癌抵抗性は著しく 低下する。そこで睡演減量，局所清揞などの操作を行な

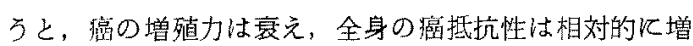

加し，局所の抵抗性の枠は修復される，局所清掃を続け

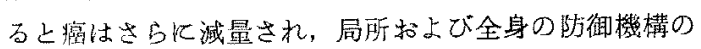

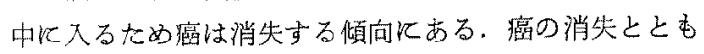
飞免疫細胞も減少し, 治撚の状熊となるわけである。し

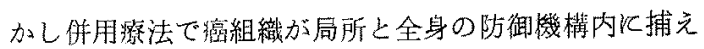
られた段階で，さら飞過剩な放射線治潦や抗癌用が投与 されると，局所の癌抵抗性の枠は破壊され，全身の免疫

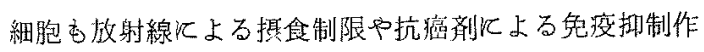
用によって，著しく機能が低下する，加えって楾が急激 に增大し，全身飞転移することもある。

担瘤個体で，免疫能が非常に低下しているという事奏 は各種免疫反応によっても証明されて执り，これは大舅

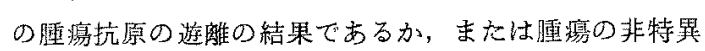
的免没物質の遊離の結果ではないかと考えられている。

これらの拉例では一般化局所の癌抵抗性も弱く，高度進 展例となりやすい。

各種免疫的検索で, 必要例にはSPG, Levamisole,PSK

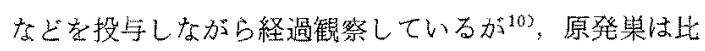
较的限局化し，組織像屯低分化型飞近小所見で，外来清 䍒で制期しうるすのが多い。

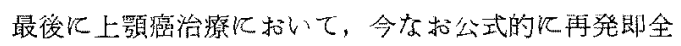
摘の説もあるが，上記のごとく免疫学的観点もらまえ，

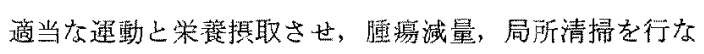
光恬，再発例こ元形態と機能を保存して社会復帰例方多 w.

\section{V. $亡 ぬ$}

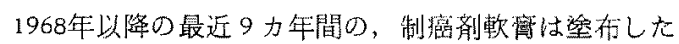

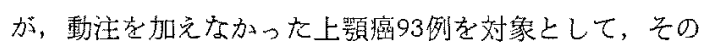
万ち再発莸み九30症例飞ついて病理分類, 再発時期上部 位件数, 再發腫滰進展度, 再発処置の実際について検討 した.

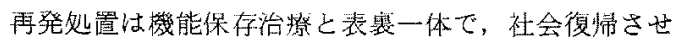
ながら経過を観祭していて，再発は唒当を括かないで好

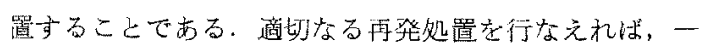
次治療配量も少なくてすみ，成績の向上飞るつながる。

再発処置の奏際として，局所清掃（すいとり，そぎ り，つみとり，活りとり)などがあげられる。

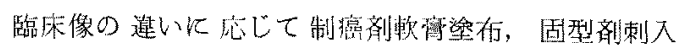
で，堙演を变性させる局所清掃する。

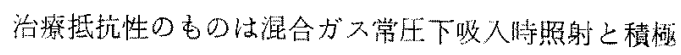
的局所清掃を併用する。

これら再発処置吕併用㜣法，集紫治燎の基本であると 考える。 


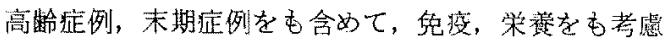
した全身との関連で, 局所腫熍の臨床像の診断に徽し，

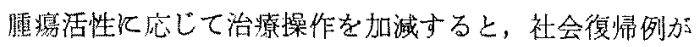
増し、今後の沿療方法の一つとして活用できるもの上考 える。

\section{参若 文 献}

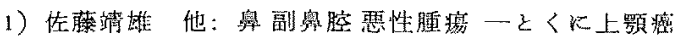
治寮について一日独医報 19；1-33，1974。

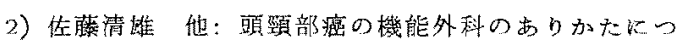
W下 耳展 20:317-359，1977.

3）佐藤綪雄 他: 頭贸部癌の機能外科のありかたにつ いて 耳䕗 23: 489-498, 1977.

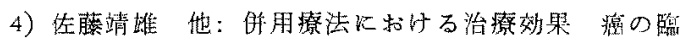
本 $23: 1118-1123,1977$.

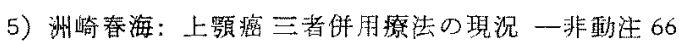
例の検討一日耳耳舅 80：1391-1402，1977。

6）高憍由美子：上顎癖三者仿用療法とくに放射線抵抗 性腫㿾の治療について 日耳多 81：214-223, 1978.

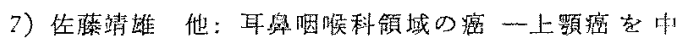
心に一癌の腹休 24: 561-567，1978，

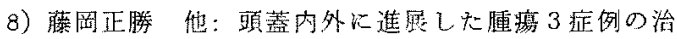

療について 耳展 21：補 1 21-38，1978.

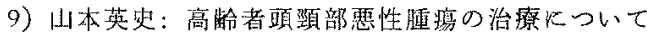
任院日数加双た治潦のありかた日耳與 81:713$721,1978$.

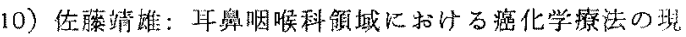
沉 臨休々研究 55: 102-111，1978.

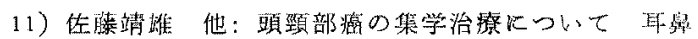
25：投稿中，1979.

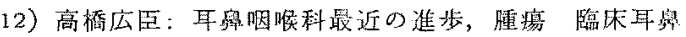
咽呢科学書上卷，金原出版 1977年度

13) Proposed draft for the third edition of the TNM classification of malignant tumors. UICC. 1978.

14) Baird Thomas: Immunology. 称沢成可莮 The Upjohn Company. 1975.

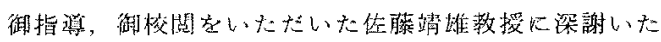
します

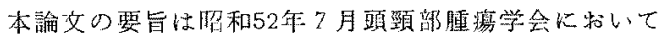
報告した。

(原稿受付 昭和53.7.31日)

別刷請求先 $\bar{T} 113$ 東京都攵京区本郷 7-3-1

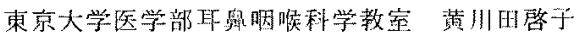

